\title{
The Military as a Moderating Power: a study with Bolsonaro supporters in São Paulo ${ }^{12}$
}

\author{
Caio Barbosa
}

\begin{abstract}
When far-right politician Jair Bolsonaro was elected president of Brazil in 2018, it marked the end of the dominance of two parties in presidential elections since 1994: the PSDB (Brazilian Social Democracy Party) and PT (Workers' Party). It also marked the return of a self-declared rightwing politician to power, which had not occurred since the end of the military dictatorship in 1985. In the 1985 mayoral elections and 1986 governor elections, the region that stretches from the beginning of the East Zone towards the North Zone in the City of São Paulo had been identified as a stronghold for the conservative right-wing vote (Pierucci 1999). This trend disappeared in subsequent elections with the lack of competitive conservative right-wing candidates. For the 2018 presidential elections, however, the region once again became a significant area of support for rightwing politics in São Paulo. This research project seeks to understand the views of the electorate in this region and their motivations to vote for Bolsonaro. Data was collected through semi-structured interviews and ethnographic observations from right-wing demonstrations, which were performed to recruit interviewees and to learn more about their agenda. Interviews were conducted with voters who campaigned for Bolsonaro in the 2018 elections and residents in the aforementioned region. This paper discusses some of the findings from this research, in particular the role of the military from the interviewees' perspective. Overall, they see the period of military rule as a positive one, associating it with virtues such as "order", "discipline", and "honesty". Research participants attribute a sort of "moderating power" to the armed forces; in their view, the military can - and should - interfere in politics if the situation demands it, even at the cost of democratic institutions.
\end{abstract}

\footnotetext{
${ }^{1}$ A previous version of this article was presented as a working paper at the Military in Politics in Brazil Conference, King's College London, on 27 and 28 May 2021.

${ }^{2}$ This study was financed in part by the Coordenação de Aperfeiçoamento de Pessoal de Nível Superior - Brasil (CAPES)

- Finance Code 001
} 
Since the 1994 election, the competition for the presidential seat in Brazil was between just two parties: the PSDB (Brazilian Social Democracy Party) and PT (Workers' Party). Therefore, it came as a surprise to most political analysts when Jair Bolsonaro was elected as president. Even with countless other candidates participating in the election and despite running for PSL (Social Liberal Party), a party that at the time was considered a minority, the electorate's united support for Bolsonaro was so great that he almost ended the race in the first round, obtaining $46.03 \%$ of the votes. In the second round, Bolsonaro won the election with $55.54 \%$ of the valid votes, defeating the PT candidate, Fernando Haddad. Explaining Bolsonaro's meteoric rise is not an easy task, especially with his aggressive, conservative rhetoric, and after four consecutive elections won by left-wing candidates. Therefore, the question arises as to where this electorate came from and what influenced their decision to support such a radical, right-wing candidate.

Bolsonaro's rise is part of a resurgence of the right in Brazilian politics. After more than a decade of PT's electoral dominance in the presidential elections, the right - mainly supported by antipetismo (opposition sentiment to the Worker's Party) - sought to reorganise its forces. Nicolau (2020) refers to Bolsonaro as the biggest leader in the Brazilian right since the end of the military regime, underlining how he attracted the support of voters despite little TV coverage during his campaign, few financial resources and little support from other political parties. Rocha (2018) analyses how new right-wing groups started organising in social networks in the 2000s, gaining prominence after large protests in June 2013 and then with Dilma Rousseff's impeachment rallies in 2015 and 2016. Singer (2021), using ideological preferences over time with Datafolha polls, shows how 2018 coincided with an increased number of respondents who define themselves as right-wing. This process, which culminated in Bolsonaro's election, led some authors to refer to a "new right" in Brazil (Codato; Bolognesi \& Roeder 2015, Ortellado \& Solano 2016, Rocha 2019).

The main hypothesis of this study is that this "new right" originated from a "hidden right" in Brazil: a considerable part of the electorate who held conservative values and did not feel represented by the main political parties (PT and PSDB). The arrival of a competitive conservative candidate, such as Jair Bolsonaro, reactivated the "new right" electoral base, which opened a rift in the whole political system, formerly stabilized by the two-party dominance for the presidential seat for over 20 years.

The right-wing electorate that is the focus of this research study felt disenfranchised by the political system and did not feel represented by the main political parties. These voters, differently from the "new right" identified by Pierucci (1999), were now proudly conservative and right-wing. They sought a candidate whose politics reflected their ideologies, and it took a seeming outsider with a radical discourse like Bolsonaro to draw the attention of these voters and see him as their representative. One of the main reasons for their support was the close association between Bolsonaro and the military. These voters corroborate a favourable view of the military regime that 
lasted from 1964 to 1985 . The association between the military and Bolsonaro, due to his status as a former army captain, helped these voters see him as the best candidate for president.

This paper will focus on the findings regarding the role of the military in the minds of rightwing voters in São Paulo. Interviewees consider the military to be a "moderating power" which can and should intervene when the country's domestic order and stability are at risk. The correlation between Bolsonaristas and militarism can be seen in supporter's association of the military with such virtues as "order", "discipline", and "honesty". The following sections will lay out the reasons for these findings, along with the methods used to collect them.

\section{Mapping the right-wing electorate in São Paulo}

This paper builds on the study of Pierucci (1995), arguing that there is a correlation between the geographic electoral base of the Janista and Malufista right of 1985 and the Bolsonarista right in 2018 in the municipality of São Paulo. One of the regions where Bolsonaro received most votes - the contiguous zone that extends from the districts of the East Zone, close to the city centre, to the North Zone - is almost the same area as where mayor Janio Quadros and governor Paulo Maluf found their respective Janista and Malufista base more than thirty years earlier (Pierucci, 1995). Furthermore, in the second round of the elections, this same region also guaranteed Bolsonaro more than two thirds of the vote.

Antônio Flávio Pierucci was a sociologist conducting studies in the years following the country's re-democratisation in the 1980s and 1990s. He performed a case study in the municipality of São Paulo regarding the elections of Jânio Quadros for mayor in 1985 and Paulo Maluf for governor in 1986. Interviewing these candidates' campaigners, Pierucci (1999) found what he called a "new right": a new wave of conservative voters who emerged with the end of the military regime. To carry out his research, he defined the geographic areas where Jânio Quadros obtained the highest concentration of votes (and roughly where Maluf would have as well in the following year). Another interesting aspect of Pierucci's mapping project is that he identified a trend in the São Paulo capital of a Janista vote among social classes in the form of an "inverted V". Jânio Quadros received few votes among the poorest populations, received more votes from the middle classes, such as residents within the aforementioned region, before falling again among the wealthy.

Pierucci (1988) had already reiterated a certain constancy in the voting preferences of these regions in different elections. In 1982, a similar region in the East Zone was where Lula obtained the fewest votes; and in 1986, Maluf obtained an expressive vote for governor in the same regions. Moreover, Sousa (1986) argues that voting for Jânio Quadros in 1985 followed the same pattern as in the 1950s when he also ran for mayor in São Paulo. Is it possible, therefore, that the presence of a competitive candidate from the conservative right revived the same electoral base in the same geographic area more than 60 years later? 
This present study returns to the neighbourhoods surveyed by Pierucci (1999), where Bolsonaro received most votes, to try to understand how his more ardent supporters think, just as Pierucci did with Jânio's and Maluf's campaigners over 30 years previously. The purpose of this study is to understand what motivated their decisions to vote for Bolsonaro in the 2018 election, what their main driving factors were, based on their view about politics, economy, morality, and other topics. Furthermore, this research also intends to identify links between the Janista and Malufista right with the Bolsonarista right, showing elements of continuity between both groups. Using semi-structured interviews and ethnographic research conducted in right-wing demonstrations in 2019, this research hopes to help in understanding the phenomenon that was the election of Bolsonaro and the emergence of this Brazilian "new right" in the early 21st century.

\section{Methodological procedures}

For this study, ethnographic observations were carried out during all the major right-wing demonstrations in 2019 in the city of São Paulo. These took place on 7 April, 26 May, 30 June, 25 August, 9 November, 17 November, and 8 December. It is noteworthy that on all these dates, rallies also took place in several cities in the country. It is not possible to attest that the findings during the São Paulo protests were replicated in demonstrations in other cities. However, São Paulo held the greatest number of protests, and generally represents the most important stage in the development of these demonstrations, so its relevance is important within the national context. These rallies were called around the country by the same groups; therefore, it is to be expected some reasonable similarity to be found across all demonstrations.

One of the purposes of participating in street rallies would be to identify residents in the regions where Bolsonaro received most votes and approach those more engaged voters with the aim of interviewing them. I took the initiative of approaching protestors with a simple questionnaire to identify whether the individual fitted the desired profile for interviews. This was in addition to going through the demonstrations, listening to the speeches made from floats and reading the different banners and placards held by the protesters. Although the questionnaire did not intend to assume the role of a quantitative survey of the demonstrations, it did help know more about those present in each of the protests, and to establish contacts with potential interviewees. The questionnaire asked for the following personal data from participants: name, age, profession, neighbourhood, number of people in their household, family income, choice for the presidential vote in 2018, whether they had campaigned for that candidate, their evaluation of the Bolsonaro government thus far, and a contact number, if applicable, for the longer interviews.

The number of successful approaches in the demonstrations ranged from 40 to 50 people. This does not include protesters who refused to answer questions in the questionnaire, which were roughly the same amount of people. In total, that meant that over 300 people were approached 
successfully across all rallies. In general, most people were limited to just answering questions when approached; others, however, took the opportunity to give their opinions - sometimes extensively on different topics, such as comments about the protest, governmental results, and dissatisfaction with opponents of the president, such as the PT, the press, Congress, and the Supreme Court. All of these comments contributed to a better understanding of the research topic.

For the interviews, the approach was similar to Pierucci's study (1999). However, unlike Pierucci, the empirical research was performed outside the electoral campaign period. This changes the dynamics of interviewee selection due to the absence of campaigns on the streets. However, even if it had taken place during the campaign, it is also true that many voters no longer campaign on the streets, but via social networks. The recruitment of respondents followed two methods. The first, as mentioned, involved recruiting participants from demonstrations carried out by right-wing groups, using small questionnaires to identify voters who may be of the profile desired by the survey and to obtain their contact details to conduct more in-depth interviews at a later stage. The second method was through snowballing: interviewees knew people who fit the desired survey profile and who could refer the researcher to other friends, acquaintances, neighbours, or family members to be interviewed.

For this study, 37 interviews were conducted, and the interviewees were selected from the districts that extend from the East Zone, which includes the electoral zones of Vila Prudente, Vila Matilde, Vila Formosa, Tatuapé, Penha de França, Mooca, up to the North Zone, in the electoral zones of Vila Maria, Santana, Vila Sabrina and Tucuruvi. In all these zones, Bolsonaro had already obtained more than $50 \%$ of the votes in the first round of the 2018 presidential elections. These districts are roughly the same surveyed by Pierucci (1999) with the exception of neighbourhoods such as Limão, and Lapa de Baixo in the West Zone. Their exclusion is justified only by the fact that their respective electoral zones (Limão in the Electoral Zone of Casa Verde, and Lapa, in its own Electoral Zone), did not reach $50 \%$ in the first round of the elections, despite expressive results for Bolsonaro. The exclusion of neighbourhoods in the southwestern electoral zones of Jardim Paulista, Indianópolis and Santo Amaro, where Bolsonaro also obtained more than 50\% of the votes in the first round, is justified because they are districts that were not surveyed by Pierucci at that time. In addition, they are not in the same contiguous area and have an average income well above the other neighbourhoods that are part of this research.

Respondents were selected according to two criteria, which are the same adopted by Pierucci (1999). The first is a regional one: residents were chosen from the electoral zones mentioned above. The second criterion was to interview voters who campaigned for Bolsonaro as voluntary activists, as well as having voted for him in both rounds. As Pierucci (1999) did in his research, this kind of voter is in an intermediate category, between the occasional voter - who voted without much thought - and the party members. This voter is characterised using a simple parameter: the interviewee tried to convince at least one other person to vote for Bolsonaro. As the research extends 
under Bolsonaro's presidency, another parameter we considered was to classify voters who participated in right-wing demonstrations from 2019 onwards in support of the government as activists. Some voters, although they were frequent participants in the demonstrations, declared that they had not tried to convince others to vote for Bolsonaro. We believe that this type of person should not be excluded, as they still fit into the activist's mould.

Although the interviews followed a script, they were semi-structured. This means that to test the hypotheses of the study, the interviews were structured in such a way that the answers were not already assumed. As Leech (2002) suggests, there are benefits to following a middle path, allowing the interviews to be open enough to include other topics, as well as adding types of more basic questions, such as "why", "how", "when", and "where". In this way, the interview allows the researcher to test hypotheses while exploring the interviewees' statements whenever possible. It was impossible to ask all the questions in the script due to limited time, so questions were asked depending on the flow of the conversation, while trying to limit the duration of the interview to about 1 hour and 30 minutes. However, interviews usually lasted longer than this, depending on the availability and receptivity of the interviewee.

Unfortunately, due to the beginning of the covid-19 pandemic in early 2020, ethnographic observations in right-wing demonstrations only occurred in 2019. About half of the interviews were conducted at the respondents' homes before the pandemic. After the pandemic started, the remaining interviews were performed by video calls or by phone, while one agreed to answer questions only via WhatsApp. The names of all interviewees were changed to ensure confidentiality and anonymity.

\section{Findings from ethnography in right-wing demonstrations in São Paulo}

After the election of Jair Bolsonaro as president of the Republic in 2018, different right-wing groups that contributed to his election remained strongly mobilized. Even with the right in power, the movements that promoted large demonstrations for the impeachment of Dilma Rousseff continued to carry out street demonstrations during the first year of Bolsonaro's government.

The use of an ethnographic methodology proved to be fundamental for understanding the phenomenon of right-wing street demonstrations throughout 2019. In ethnography, the researcher alone cannot always be present and witness everything that happens throughout an entire demonstration. After all, the space under observation is not, and should not be, controlled (Harrington, 2003). However, participant observation reveals nuances that a distant perspective does not cater for. As De Volo and Schatz (2004) point out, while ethnography alone cannot be used for statistical reliability, it makes gains through the validity of its findings. 
Protests and rallies are interesting places to conduct ethnographic observation, especially when studying a political group. As Van Stekelenburg and Klandermans (2013) claim, identities that are politicised are one of the main engines of collective action, and the continuous rallies to support the government evidenced their identity, making these protests an ideal place to find interviewees and to learn more about the agenda that motivated them. Also, protests are an important place to seek access to groups that are difficult to engage with, and as Harrington indicates, "access is the defining activity of ethnography" (Harrington, 2003: p. 594). And as Walsh (2009) affirms, with other methods, the people we study are enticed to reveal only part of themselves, while ethnography allows people to be themselves in the environments of their choice.

All the demonstrations attended were held on Paulista Avenue, the most well-known avenue and the usual stage of protests in São Paulo. For this ethnographic study, I remained in each rally for an average of four hours, and my observations were divided into two distinct moments. In the first hour, I was "in disguise" without anything to characterize myself, the author, as a researcher; I was just one more member in the crowd. It was therefore possible to pay full attention to speeches and other elements during the protests without interfering in the observed space. Later, after moving through the protests, I would put my badge of postgraduate researcher from the University of São Paulo (USP) around my neck, which allowed people to know my role there for the remaining three hours.

Timothy Pachirat (2009) discusses the theoretical hypothesis of what it would be like to take an invisibility potion to perform ethnography without the researcher interfering in the object. Thanks to the nature of the demonstration, at first it was as if I had taken the invisibility potion, as there was nothing to make me stand out from other demonstrators. However, as soon as I put the badge on, it was as if the potion's effect disappeared. In the distance, a few viewed my badge with curiosity, pointed at me, between whispers and giggles, highlighting my presence. The majority of protesters who I approached were cordial and agreed to answer questions. The rest reacted in different ways: some were suspicious of the intentions of the questions and preferred not to answer; others treated with scorn, saying that they would not speak to someone from the left, since USP was a den of leftists, among other things; and a few were still a little more aggressive, and took the opportunity to speak out against universities and the left in general. It must be noted that no physical aggression ever happened, and although there was some hostility, the negative reactions were more playful and mocking than truly aggressive, despite the occasional rudeness. No attempt was made on my part to confront or discuss the beliefs that the protesters might have held about the research, universities, or my purpose there.

Each demonstration had a particular reason or main theme. Overall, however, they were to show support for the Lava Jato Operation (and its political agenda) and for the government, which actively or covertly encouraged protestors to show resilience. There were groups and individuals with their own agenda in all rallies, which were different from those called by the organising bodies. 
One of the most striking agendas was that of the intervencionistas: groups and individuals who called for military intervention.

A military intervention means, according to protestors, using the military to fight against those who opposed Bolsonaro. This usually implied closing Congress and the Supreme Court with the help of the military, or arresting Bolsonaro's political enemies. Many felt there was nothing wrong or even authoritarian about this intervention. This is due to their misinterpretation of Article 142 of the Brazilian Federal Constitution, which grants the president the power to use the military for these purposes. This was an important idea for protestors: they did not want the military to take power, they merely wanted them to consolidate Bolsonaro's unopposed rule.

The intervencionistas were present in varying numbers across all demonstrations. In solely Lavajatista demonstrations, they were usually less present, while in Bolsonarista rallies they were clearly more comfortable being there. For the demonstration on 26 May 2019, Lavajatistas decided to not attend the rallies because the calls for protests were considered anti-democratic, including demanding the closure of Congress and the Supreme Court. Bolsonaro publicly asked his supporters not to take banners calling for this agenda. His followers acquiesced, although a few such banners and placards were still present on the day.

Overall, intervencionistas were accepted, tolerated or, at best, ignored by the leading organising groups. While their floats were usually set apart from the main group, banners and placards calling for military intervention could be seen throughout the protests. From the floats, different people would give speeches, some of them dressed in military outfits. On 30 June, one man introduced himself as an Army sergeant, although it was unclear if they were indeed members of the armed forces, or just dressed in a costume. This man spoke freely about how the rally was important to "kill for once and for all these communist, left-wing nutjobs", to which the usually smaller crowd would reply "we want intervention!" or "Aço!" ("Steel”, which is a form of military greeting).

Even when they did not mention military intervention, antidemocratic speeches commonly occurred during the rallies. On 7 April, one of the activists speaking from a float argued for the end of the Supreme Court. They claimed that it was not anti-democratic, as they did not want to close it completely, but wanted to substitute it for a "more representative" Court, since the current one was not "democratic". On 8 December, Carla Zambelli, a federal congresswoman, and leader of the NasRuas movement, addressed the end of the Supreme Court. She argued that the idea "was good in practice" but was not the best path to take "now". According to her, doing this would lead to "a great legal uncertainty", especially in a moment "when Brazil is recovering its image abroad". 


\section{The call for "order": the military in the eyes of interviewees}

While ethnographic observations in right-wing rallies helped to understand the plurality of the right-wing groups that supported Bolsonaro, the semi-structured interviews with Bolsonaro campaigners allowed a deeper understanding of their motivations. Furthermore, they confirmed the hypothesis that these voters felt disenfranchised from the main political parties. The interviewees of this study were proudly and outspokenly conservative or right-wing. This differs from what Pierucci (1999) found among Janistas and Malufistas in his study. The defiant conservatism in 2019 was a major change from a political phenomenon that occurred after the end of the military regime, known as the "embarrassed right" (Souza 1988; Mainwaring, Meneguello \& Power 2000). Conservative political parties and their corresponding electorate avoided declaring they were rightwing, even if they held such values. That was entirely different for Bolsonaristas who were seeking a candidate that was just as outspokenly right-wing as they now were.

As well as seeking an outspoken conservative candidate, these supporters were motivated by their opposition to PT, or antipetismo. This encompassed a wide spectrum of ideas, such as opposing handouts to the poor, and reacting against corruption scandals from within PT and their economic policies. Antipetismo is also seen in a cultural backlash to the advances that political minorities have had in recent decades, such as women, African-Brazilians, and LGBT groups (Hochschild 2016, Norris \& Inglehart 2019). The Bolsonarista backlash can also be seen in their views of the military and the relationship between Bolsonaro and the Brazilian Armed Forces.

As Bolsonaro is a former army captain and has campaigned for most of his life to defend the military regime and the rights for lower-ranking officers, the question of militarism naturally arose in interviews. In this respect, Bolsonarista differ from Malufistas and Janistas, for whom militarism did not appear to be an issue. The military has been present in Brazilian politics since the colonial period in Brazil. After the end of the military regime, the military became less involved in different areas of government. However, after the Michel Temer's government following the impeachment of Dilma Rousseff, a significant number of military personnel were called on to participate in government. With Bolsonaro in power, the participation of members of the Armed Forces in his government was even greater, occupying at least 2,500 positions (Mattoso \& Bragon 2019).

Bolsonaro campaigners in general viewed the participation of military personnel in government in a positive light. Some voted for Bolsonaro for this very reason. In the imagination of this electorate, the military has an important role in the country to impose "order" and "respect". Moreover, the military was seen as a bastion of "honesty" and "discipline". These values were broad enough to encompass many ideas for these voters. "Order" meant controlling urban violence, but also social unrest and political turmoil. "Honesty" and "discipline" mostly meant respect towards taxpayers' money, not getting involved in corruption, as many repeated the idea that huge corruption scandals were not heard of during the military regime (this does not mean, however, that 
corruption did not occur). Therefore, for voters worried about crime, corruption, and who were disillusioned with the political system, especially in the aftermath of the Lava Jato operation, the military seemed a safe option for troubled times. This is revealed in Mariana's responses below:

- [...] thinking about this order, honesty thing; you think that a military man, a policeman ... you have this sweet illusion that they are going to establish order, right?

- Order in what sense?

- Order of things to be fairer, to be more honest, of him not accepting these alliances out of interest, although politics is an alliance of interest and you do one thing for one, for another to do for you.

- Is that the image you had of the military?

- That was the image I had of the military, and today, from what I can see... [...] it is a mess because they are fighting amongst themselves, it will not get anywhere. (Mariana, 36, commercial manager - resident of Vila Prudente).

The positive view of the military among Bolsonaristas was likely influenced by their view of the military regime. Most interviewees corroborated the story that the 1964 coup was necessary to prevent Brazil from becoming a communist country. Many respondents highlighted positive points about the regime, even in a nostalgic way, claiming that they or their parents had not had any problems with the regime. A repeated word was "respect": respondents claimed that "At that time, there was respect", or things "worked". Other interviewees also mentioned patriotic values, which were mostly lost in the democratic transition. Most acknowledged, though, that there had been excesses from the military, either in torture or for having been in power for too long.

There was no apparent significant difference regarding trust and a positive impression of the military between older interviewees who had lived during the military regime and younger ones who had not. Younger respondents were usually influenced by their parents' or grandparents' opinions, often quoting what they had heard from them, as in the case of Marcelo:

I think it is funny that many people from that time, who today, right, are older, obviously say like this "It was good during the Military Regime", you must have heard that, right? People said, "It was good in the Military Regime because things worked, things, like, I had respect". (Marcelo, 25 years old, commercial manager - resident of Tucuruvi).

This general trust in the military is corroborated by the Latinobarometro survey in 2018 . Respondents were asked to view a card of groups and institutions and say how much they trusted each of them. Results showed high levels of trust in the Armed Forces across all age groups in Brazilian respondents. In the survey, around a third of people aged 15 to over 61 expressed "a lot of confidence" in the Armed Forces, with another third expressing "some confidence" across the same age brackets. This same trust and confidence in the military was similarly expressed by respondents for this present study, as in the words of Lucia: 
And I say, what was good about the Military Regime? The values. People had the respect of... I miss it. We marched on September 7th, put it on, put a green and yellow ribbon on the chest, the pinwheels in the cars, there was the civic parade, so we had that thing of encouraging love for the country because it seems that when the regime was over, the homeland was over, there is no more love, there is nothing else. (People) only remember love for their country at the time of the World Cup, but after Neymar, they have stayed away because they lost by seven to one, so not even to support the country. So, what I miss during the Military Regime was that, patriotism. And one of the reasons I also voted for Bolsonaro was because he wanted to bring this patriotism thing back. You ask people, "What does November 15th celebrate?" "I don't know, I just know it's a holiday and I'm going to the beach" "What is celebrated on September 7th?" "I do not know". (Lucia, 50 years old, police officer - resident of Tucuruvi).

For the interviewees of this study, the military embodies essential values which voters longed to see reflected in the political system. Even with the transition to democracy, the military retained an important role in politics for Bolsonaristas. This was not the case for Janistas and Malufistas that Pierucci (1999) found, as they were still part of the "embarrassed right" following the end of the military regime. However, over 30 years later, as Brazilian politics and society descended into chaos, following an economic, political, and moral crisis, seen in the cultural backlash mentioned previously, these voters sought refuge in the military. And if military intervention was not possible, then electing Bolsonaro appeared to be the easiest path to achieve their ideals.

For these right-wing voters, the military has the responsibility of a "moderating power" in Brazil. Should the need arise - as it did in 1964 - the military has a duty of intervening in the affairs of the political regime and over democratic institutions, as it represents the most important and respected institution in Brazil. These voters perceive the military as guardians of domestic order in the country, as opposed to a defence against a foreign threat.

The interviews revealed a low democratic sentiment among these voters. There was strong discredit concerning Congress, political parties and the Supreme Court. As mentioned, a recurring topic in right-wing demonstrations, but also in the social networks of these groups, is the idea of military intervention, some claiming that this would be supported by the Brazilian Federal Constitution. And, in fact, a few respondents openly supported the idea. This could come as a surprise: if they were asked which was better, everyone agreed that democracy was better than a dictatorship. Nevertheless, it was easy for some to see a context in which a military intervention or just any authoritarian move would be justified or desirable, as in the words of Vitor and Sindoval:

Because I think the military is the country's greatest power, like this. I think that if the country happens to be going into a political crisis or something, Civil crisis, civil war ... I think they need to intervene to put things in order. (Vitor, 25 years old, unemployed resident of Tucuruvi). 
- Do you think that if Bolsonaro defends that he needs to make a military intervention, do you think that you will support it too?

- Oh yes, if making a military intervention is necessary, I will support it, because I think that if he goes this far it is because it really is a necessity. He made a statement - I have his statement there - that he said that he would never do such a thing, to use military intervention to be able to block some system, but only that it is extremely dangerous. This Supreme Court is really doing things ... that makes us very sad, supporting bad guys, letting bad guys go, it is too much. (Sindoval, 55 years old, electrician - resident of Vila Guilherme).

It should be noted that just a few respondents openly supported military intervention in the sense of a coup. Nonetheless, it was easy for many interviewees to consider it a possibility under certain circumstances. These include if Bolsonaro deemed it necessary, the arrest of supposedly corrupt politicians or members of the Supreme Court, the censorship of the press or banning of political parties, especially PT. These ideas were not necessarily seen as antidemocratic, as the same people clearly expressed a preference for democracy over a dictatorship, which also showed how they failed to defend or understand some basic principles of democracy. In their view, by intervening in a chaotic and corrupt scenario, the military would be helping to preserve democracy - which usually meant helping Bolsonaro, who was elected by majority vote, against his enemies not acting against it.

\section{Conclusion}

This paper is part of a broader research project to better understand the 'new right' that helped elect Bolsonaro. Focusing on the municipality of São Paulo, this study has revisited a region that was previously considered a bastion of the conservative vote in the city - and that again appeared as a conservative base for Bolsonaro in 2018. For this study, campaigners were interviewed to investigate their motivations for supporting the current president. At the same time, ethnographic observations were conducted in a series of large demonstrations by Bolsonaro's supporters throughout 2019, both to recruit interviewees and to learn more about their agendas.

The motivations and values of the far-right voters interviewed for this research proves the following hypotheses: many of these voters were nostalgic for the military regime and saw the return of the military to government (as Bolsonaro was a former army captain) as a positive move to reestablish some degree of "order"; these voters were reacting to the economic and social policies implemented by the former PT government to reduce inequality, they were moved by a sentiment of meritocracy and felt relatively worse off than before with the ascension of poorer classes; and these voters were resisting the rise of political minorities, such as women, black and, especially, LGBT groups. 
The views of people interviewed for this study reflect the inability that Brazil has had to overcome the close relationship between the military and politics throughout the country's history. This differs to its neighbours such as Chile and Argentina. Furthermore, the views expressed by Bolsonaristas shed light on the enduring authoritarian legacy in Brazilian history, particularly in the political right, which adheres to anti-democratic principles even after 30 years of the end of the military regime. Therefore, it remains a challenge for Brazil to consolidate a competitive conservative right-wing party that is attuned to democratic values and to keep the military out of the electorate's mind as plausible alternatives.

\section{Bibliography}

Codato, A., Bolognesi, B. and Roeder, K. M. (2015) 'A nova direita brasileira: uma análise da dinâmica partidária e eleitoral do campo conservador' in Velasco e Cruz, S., Kaysel, A. and Codas, G. (eds.) Direita, Volver! O retorno da direita e o ciclo político brasileiro. São Paulo: Fundação Perseu Abramo, pp. 115-144.

De Volo, L. B and Schatz, E. (2004) 'From the inside out: Ethnographic methods in political research' in PS: Political Science \& Politics 37.2, pp. 267-271.

Harrington, B. (2003) 'The social psychology of access in ethnographic research' in Journal of Contemporary Ethnography 32, no. 5, pp. 592-625.

Hochschild, A. R. (2016) 'Strangers in their Own Land: Anger and Mourning on the American Right'. The New Press, 2016.

Latinobarometro (2018). Available at: https://www.latinobarometro.org/latOnline.jsp. (Accessed: 27 December 2021).

Leech, B. (2002) 'Symposium: Interview Methods in Political Science' in PS: Political Science and Politics 35(4), pp. 663-664.

Mainwaring, S., Meneguello, R. and Power, T. (2000) ‘Partidos conservadores no Brasil contemporâneo: quais são, o que defendem, quais são suas bases'. São Paulo: Paz e Terra.

Mattoso, C. and Bragon, R. (2019) 'Bolsonaro amplia presença de militares em 30 órgãos federais', Folha de S. Paulo, October 14th, (online) Available at: https://www1.folha.uol.com.br/poder/2019/10/bolsonaroamplia-presenca-de-militares-em-30-orgaos-federais.shtml. (Accessed: 29 August 2021).

Nicolau, J. (2020) ‘O Brasil dobrou à direita: uma radiografía da eleição de Bolsonaro em 2018’. Rio de Janeiro: Zahar.

Norris, P. and Inglehart, R. (2019) ‘Cultural Backlash: Trump, Brexit and Authoritarian Populism’ . Cambridge: Cambridge University Press.

Ortellado, P. and Solano, E. (2016) `Nova direita nas ruas? Uma análise do descompasso entre manifestantes e os convocantes dos protestos antigoverno de 2015' in Dossiê: As Direitas no Brasil, n. 11, ano 7, Fundação Perseu Abramo.

Pachirat, T. (2009) 'Shouts and Murmurs: The Ethnographer's Potion' in Qualitative and Multi-Method Research Newsletter, 7, pp. 41-44. 
Pierucci, A. F. (1987) 'As bases da nova direita' in Novos Estudos - CEBRAP, São Paulo, no 19, December, pp. 26-45.

(1988) 'A direita mora do outro lado da cidade' in GT Partidos, Eleições e Problemas Institucionais, XII Encontro Anual de Anpocs, Águas de São Pedro, SP, October.

(1999) Ciladas da Diferença. São Paulo: Editora 34.

Rocha, C. (2018) '“Menos Marx, Mais Mises”: Uma Gênese da Nova Direita Brasileira (2006-2018)' São Paulo: PhD Dissertation defended at Universidade de São Paulo. Paulo, 6 May.

. (2019) A emergência da nova direita e o bolsonarismo. Seminar presented at Universidade de São

Singer, A. (2021) 'A reativação da direita no Brasil' in Scielo, January. Available at: https://preprints.scielo.org/index.php/scielo/preprint/download/1664/2648/2768. (Accessed: 30 December 302021.

Sousa, M. T. S. R. de. (1986) ‘A Trajetória de Jânio Quadros' in Lamounier, B. (org.) 1985: O Voto em São Paulo. São Paulo: IDESP.

Souza, M. do C. C de. (1988) ‘A Nova República sobre a espada de Dâmocles' in Stepan, A. Democratizando o Brasil. São Paulo: Paz e Terra.

Van Sketelenburg, J. \& Klandermans, B. (2013) 'The social psychology of protest' in Current Sociology Review, 61(5-6) pp. 886-905.

Walsh, K. C. (2009) 'Scholars as Citizens: Studying Public Opinion through Ethnography' in Schatz, E. (ed). Political Ethnography: What Immersion Contributes to the Study of Power. Chicago and London: The University of Chicago Press. 